\title{
Long term efficacy and safety of canakinumab in children with systemic juvenile idiopathic arthritis with and without fever
}

\author{
G Horneff $^{1 *}$, N Ruperto ${ }^{1}$, H Brunner ${ }^{2}$, P Quartier ${ }^{3}$, T Constantin' ${ }^{1}$, E Alexeeva' ${ }^{1}$ I Kone-Paut ${ }^{1}$, K Marzan², N Wulffraat ${ }^{1}$,

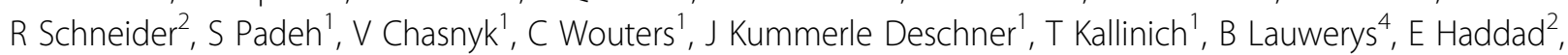

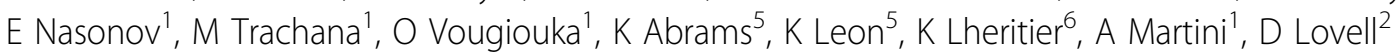

From 8th International Congress of Familial Mediterranean Fever and Systemic Autoinflammatory Diseases Dresden, Germany. 30 September - 3 October 2015

\section{Introduction}

Rapid and sustained efficacy of canakinumab (CAN) were previously demonstrated in patients with systemic juvenile idiopathic arthritis (SJIA) [1]. However, little is known about potential differences in response to CAN treatment between patients with vs. without SJIA-associated fever at the time of the first CAN administration.

\section{Objectives}

To evaluate the long-term efficacy and safety profile of CAN-naïve SJIA patients with and without SJIA-associated fever.

\section{Patients and methods}

patients aged 2-20 years with SJIA with and without SJIA associated fever at enrollment received open-label CAN $4 \mathrm{mg} / \mathrm{kg}$ s.c. every 4 wks. Every 3 months, response to CAN was measured by adapted JIA ACR response criteria (aACR/JIA); juvenile arthritis disease activity score (JADAS); clinical inactive disease; clinical remission on medication (CRM, 6 months continuous clinical inactive disease). Safety was assessed monthly.

\section{Results}

Data on 122/267 patients, 53 (43\%) with and 69 (57\%) without SJIA associated fever, were available for analysis with a median 94 wk study duration. At Wk4, $75 \%$ of both subgroups had responded ( $\geq$ aACR/JIA30), increasing to $90 \%$ at Wk12. At Wk2, 21\% of both subgroups had inactive disease; $44 \%$ at Wk8; $60 \%$ at Wk20 and

\section{'PRINTO-Istituto Gaslini, Genova, Italy

Full list of author information is available at the end of the article then $60-70 \%$ for the remainder of the trial. CRM was achieved in about $29 \%$ of patients in both subgroups with $\sim 22 \%$ maintaining it for $\geq 12$ consecutive months. At baseline, the median JADAS score was 21.5 with $8(7.5 \%)$ and $99(92.5 \%)$ patients meeting the criteria for moderate (JADAS $>3.8$ and $\leq 10.5$ ) and high disease activity (JADAS $>10.5$ ), respectively. At Day 15, the median JADAS was 6.8 and 1.5 at the last assessment. At the last assessment, 53 (48\%) patients had inactive disease (JADAS $\leq 1) ; 10$ (9\%) with low active disease activity (JADAS $>1$ and $\leq 3.8$ ); while $14(13 \%)$ had moderate and $31(28 \%)$ with high disease activity. Infection (0.56 infections/100 patient-days), typically involving upper respiratory tract was the most common type of adverse event. Fifteen patients discontinued due to an $\mathrm{AE}$ and 40 had $>1$ SAE (mostly infections, macrophage activation syndrome (MAS), or flare-associated) and no deaths. Eight cases of MAS (0.013 events/100 patientdays) were reported.

\section{Conclusion}

Canakinumab provides similar efficacy in SJIA patients with and without SJIA-associated fever at treatment onset. The long-term safety profile was acceptable and similar to the pivotal program in SJIA children with fever at enrollment.

\footnotetext{
Authors' details

${ }^{1}$ PRINTO-Istituto Gaslini, Genova, Italy. ${ }^{2}$ PRCSG, Cincinnati, OH, United States. ${ }^{3}$ Necker-Enfant Malades Hospital, Paris, France. ${ }^{4}$ Cliniques Universitaires SaintLuc and Université Catholique de Louvain, Brussels, Belgium. ${ }^{5}$ Novartis Pharmaceuticals Corporation, East Hanover, NJ, USA. ${ }^{6}$ Novartis Pharma AG, Basel, Switzerland.
} 
Published: 28 September 2015

\section{Reference}

1. Groom JR, Luster AD: CXCR3 ligands: redundant, collaborative and antagonistic functions. Immunol Cell Biol 2011, 89(2):207-15.

doi:10.1186/1546-0096-13-S1-083

Cite this article as: Horneff et al:: Long term efficacy and safety of canakinumab in children with systemic juvenile idiopathic arthritis with and without fever. Pediatric Rheumatology 2015 13(Suppl 1):083.

Submit your next manuscript to BioMed Central and take full advantage of:

- Convenient online submission

- Thorough peer review

- No space constraints or color figure charges

- Immediate publication on acceptance

- Inclusion in PubMed, CAS, Scopus and Google Scholar

- Research which is freely available for redistribution

Submit your manuscript at www.biomedcentral.com/submit
Ciomed Central 